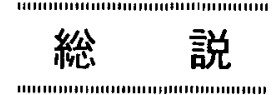

\title{
ナノ化によって材料に何が期待されるか*
}

\section{(蜯)豊田中央研究所 上垣外修己}

Osami Kamigaito : What Can Be Improved by Nanometer Composites?

Significance of the constitutional size in the composites having the constitution of nanometer size (Nano-Composites) was emphasized. Every Nano-Composite should have two critical values, the upper limit and the lower limit, for the dimension of the constitution to posses the distinguishable property as Nano-Composite. The critical values depend on the property expected for the composite. The values were estimated or re-viewed on various basis which are thought to be useful for each property, such as catalytic activity, magnetism, optical property as well as mechanical one. For examples: The range of the binding force acting across the surface of solids was estimated from the surface free energy and the ideal strength, which gives the critical value in general expression for the constitutional dimension and also for one basic aspect of catalitic activity. The values are about $7 \mathrm{~nm}\left(\mathrm{Si}_{3} N_{4}\right), 4 \mathrm{nn}(\mathrm{SiC}), 4 \mathrm{~nm}$ $(\mathrm{Al}), 2 \mathrm{~nm}(\mathrm{Fe}), 2 \mathrm{~nm}(\mathrm{~W})$ and $3 \mathrm{~nm}(\mathrm{Pt})$. The value is very small for oxides, $0.5 \mathrm{~nm}\left(\mathrm{Al}_{2} 0_{3}\right)$ and $0.4 \mathrm{~nm}(\mathrm{Mg} 0)$ probably due to screening effect on the surface. As to magnetic properties, 100 nin for super paramagnetism's occurrence and $20 \mathrm{~nm}$ for making the originally hard magnetic material soft one. 0ptically, the value is about $50 \mathrm{~nm}$ for reflective intex change. Mechanically, it is about $100 \mathrm{nn}$ for strengthning or restricting dislocation movement. Some improved properties, which could be expected or have been realized, are described in the relation with the critical values.

(Received February 4,1991)

\section{$\S 1$ 緒言}

均質な材料の持つ利点を伸ばし、その久点を除去する 目的で多くのマクロ的複合材料が考案され幾つかの材料 は期待通りの性能を示し、実用的にも重要な材料として その地位を確立している。

複合材料のこのような成功は、究極的には組樴を徹底 的に微細化して襩合材としての特性を極限にまで高めよ うとする研究に発展して来ている。一方でまた均質系の 持つ優れた挙動の研究結果からは”不均貿が均一に分散 した系”に高い期待が寄せられ、結果としては超微細組 䄉を持つ複合材料に多くの分野からの注目が集められる 事になって来ている。高分子分野においてはモレキュラ 一コンポジット、ハイブリッド材料、金属·セラミックス 分野ではナノ復合材料と呼はれるものがそれである。本 稿ではこれらをまとめてナノ複合材料と呼ぶことにする。

ナノ複合材料に多くの期待が寄せられているのは上に 述べた通りであるが、その実体には不明確な点が多いよ うに見受けられる。例えは、単に組織寸法をナノメータ にすればナノ複合材料と呼び得るのか、即ち、ナノメー 夕組笺は従来の複合材料と真に質的に異なりうるのか等 に関して明確な理由が示されていないように見受けられ る。この事は逆に、ナノ複合材に対する期待を不明確に し、良くも悪くも不当な評価をナノ複合材に与えること にもなり兼ねないものと考えられる。

本稿では、ナノ複合組轼の寸法がどの程度になれはナ ノ複合材料と呼ひうるようになるか（臨界寸法）、その 材料にどの程度の性能が期待できるか等をできるだけ明 らかにし、最近のこの分野での成果の実例などについて 简単に䊅介したい。

\section{$\S 2$ ナノ䙡合材料の棈造的特徽}

ナノ要合材料が実現したと仮定すると、この材料には 搆造的に組織の寸法の上限、下限の二つが存在すること がわかる。

すなわち、A，B二つの相から成る䙓合材料を考える とき、組織の寸法が充分に大きければ、これは通常の意 味での复合材料（マクロ複合材料）である。組䄉を微細 化して行くと $\mathrm{A}$ 、B両相の界面が増加し、これと共に $\mathrm{A}$ 相の内部にある原子と $\mathrm{B}$ 相の内部にある原子とが直接の 相互作用を始め、二つの相は搆造的にはA相、B相とし ての特幑を有しながら、結合特性的には両相の中間的な いし䙓合的な性格を具偏するようになる。さらに、組䡴 が微細化すれば、A相を構成する原子と B 相を構成する 原子とが交互に配䈯される構造、すなわち、安定ないし

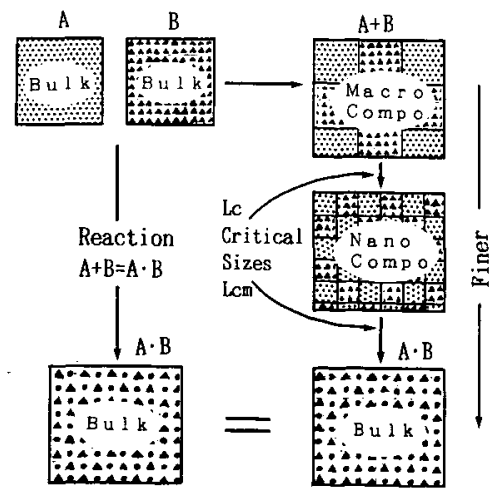

Fig. 1 Critical sizes for Nano-Composite in the relationships among various composites $(A+B)$ and Compound $(A \cdot B)$.

*枌体粉末治金協会平成 2 年度秋季大会特别講演 
は不安定な化合物あるいは固溶体と化する（図 1 ）。

ナノ複合材料と呼び得る材料は、上の説明で、A，B 雨相がそれぞれの構造を維持しながら直接の相互作用を 通して、特性的に $\mathrm{A}, \mathrm{B}$ 相単独の存在におけるとは異な つた状態にあるか、あるいはA，B相単独の存在下で存 在する協力現象が、A，B両相の相互作用を通じて消失 するかの状惥にある材料と考えられる。

このように考えると、ナノ複合材料の組織は $\mathrm{A}, \mathrm{B}$ 両 相の相互作用が少なくとも一相の内部に及び始める值を 上限とし、 $\mathrm{A} 、 \mathrm{~B}$ 粠成原子が化合物を形成し始める值を 下限とする二つの臨界寸法を持つことがわかる。これが ナノ愎合材料の一つの棈造的特徵である。もう一つの特 徵は先に述べたように界面が増加し、界面に存在する $\mathrm{A}$ $\mathrm{B}$ 両相の原子数が増加し、かつ界面エネルギが系全体の 中で大きな割合を占める事である。界面の立場で言えば 界面相(界面と言える空間内にある相)に属する原子の数 が全体の $50 \%$ を越すような組樴寸法がナノ裸合材料の 陁界寸法の上限と考えられる。また、界面エネルギの立 場で言えば、界面相の持つ過剩エネルギが化合物或いは 固溶体生成エネルギ、或いは系全体のエネルギのような 組较寸法がナノ複合材料の臨界寸法の上限に対応しよう。

\section{§3ナノ複合材料における臨界寸法}

前章に述べたナノ䙓合材料の特徴的寸法は対象とする 材料、特性によって異なる。これについて以下にやや詳 しく述べる。

$3 \cdot 1$ 表面自由エネルキ（材料内の結合力の到達距 離）の立場から

A、B両相の間の相互作用から臨界寸法を考えるにも、 界面相の原子数から臨界寸法を考えるにも原子間で働く カの到達距離 $\mathrm{L}$ 质知ることが必要である。

L r は表面自由エネルギ $\gamma_{s}$ と理想強度 $\sigma_{\mathrm{id}}$ の比から求 められる。すなわち、 $\gamma_{\mathrm{s}}$ は固体をある平面で分割して、 生ずる二つの固体を無限大の距離にまで引き離すときに なす仕事Wを二つの新生表面の全表面積 $2 \mathrm{~S} て ゙$ 除した值 (=W/2 S ) で与えられる。

ところで、上に述バた仕事は、分離される二つの面の 間に働く力 $\mathrm{F}$ を分離開始点 $\mathrm{y}_{0}$ から無限大までの距離ま で積分すればよいので、Fを二面の間の距離 $\mathrm{y} の$ 関数と して、F(y)と書くと $\mathrm{F}\left(\mathrm{y}_{0}\right)$ は固体の破断が生ずる時、

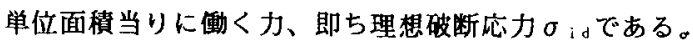
$F(y)$ を指数関数で近似し、Fが $\sigma_{\mathrm{id}}$ の $\mathrm{e}^{-2}$ 管になる距 離を L rと考えると、L (は次式で与えられる ${ }^{1) 。 ~}$

$$
\mathrm{L}_{\mathrm{s}}=4 \gamma_{\mathrm{s}} / \sigma_{\mathrm{id}}
$$

の jdは種々の方法によって近似されるが、原子間に働 く力は、原子の周りの電子分布が一定であれば、原子間 の匝離のみの関数で運動状態には無関係であること、理

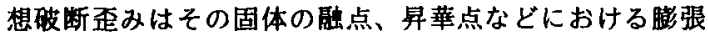
量より大きくはないと言う結論などを利用した近似によ ってかなり精度よく与えられ、次式で計算される21、3。 $\sigma_{\mathrm{id}}(\mathrm{T}) \geqq 3 \int_{\mathrm{T}}^{T x} \alpha \mathrm{E} /(1-2 \mu) \mathrm{d} \mathrm{T}$

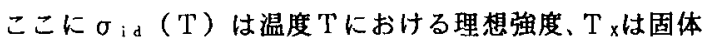

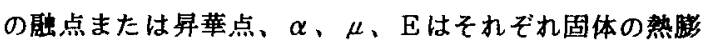
張率、ポアソン比、弹性率である。(5)の精度は室温のウ イスカ強度との比較で士 $20 \%$ 以下の虽差内である。

(1)、(2)から $\gamma_{\mathrm{s}}$ の椡定值を用いて、各種材料のL $\mathrm{f}$ が計 算される。主要な材料についてのL，は表 1 に示される 通りで、酸化物では $0.1 \mathrm{~nm}$ 以下、炭化物・窒化物では $0.5 \mathrm{~nm}$ 程度、金属では $0.2-0.4 \mathrm{~nm}$ 程度である。酸

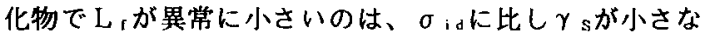
ためであり、これは二面の分離により表面近傍で奄子分 布の再配列が生じ電場を遮蔽する効果が生ずるためと理 解され、固体内部では金属並みないし窒化物並みのL， の値になっていると推定される。表 1 の $\mathrm{f}$ の值は関数 $\mathrm{F}(\mathrm{y})$ )選び方にもちろん依存するが、F(y)を直線で 近似しても全く同一であり、現実の值と大差ないと推定 される。また、 $\gamma_{\mathrm{s}}$ の測定做には比較的大きな誤差が含 まれるが、表 1 の計算に用いられている $\gamma_{s}$ の値は原子 化熱と配位数から推定した値にほほ近く、これの誤差も それはど大きくはないと推定される。即ち表 1 の L $\mathrm{r}$ は 実際の値をかなりよく近似しているものと考えられる。

さて、表 1 のL，を基にしてナノ襩合材料の䠛界寸法 の上限 L cを推定すると、以下の値を得る。すなわち、 結合の到達距離は L fであるので、無限厚さの固体の表 面層の厚さは Lrと推定される。Lの厚さの表面層内で は、結合力はほとんど固体内部から働き、Lより深い 部分に働くカがその周曲からほほ均等に由来するのと大 きく異なるからである。それゆえ、複合材料が積層膜の ように無限平板的である場合には、一つの相内で表面層

Table 1 Force Range and Some Critical Sizes for Various Material.

\begin{tabular}{|c|c|c|c|}
\hline $\mathrm{Mat}$ & $\begin{array}{c}\text { Force Range } \\
\left(\begin{array}{c}\left.L_{\mathrm{f}}\right) \\
(\mathrm{nm})\end{array}\right.\end{array}$ & 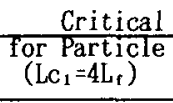 & $\begin{array}{l}\text { Size }(\mathrm{nm}) \\
\text { for Disper- } \\
\text { soid }\left(\mathrm{L}_{\mathrm{CS}}=7 \mathrm{~L}_{\mathrm{f}}\right)\end{array}$ \\
\hline $\begin{array}{c}\mathrm{MgO} \\
\mathrm{A}_{2} \mathrm{O}_{3} \\
\mathrm{~S} \mathrm{iC}^{\mathrm{i}} \\
\mathrm{S} \mathrm{i}_{3} \mathrm{~N}_{\mathrm{A}} \\
\mathrm{A} \mathrm{I} \\
\mathrm{Si} \\
\mathrm{Fe} \\
\mathrm{C} \mathrm{O} \\
\mathrm{Ni} \\
\mathrm{Cu} \\
\mathrm{Rh} \\
\mathrm{Pd} \\
\mathrm{Ag} \\
\mathrm{W} \\
\mathrm{Pt} \\
\mathrm{Au}\end{array}$ & $\begin{array}{l}0.05 \\
0.07 \\
0.4 \\
0.7-1 \\
0.3-0.6 \\
0.9 \\
0.2 \\
0.2 \\
0.2 \\
0.3 \\
0.2 \\
0.2 \\
0.2 \\
0.2 \\
0.4 \\
0.2\end{array}$ & $\begin{array}{l}0.2(2) \\
0.3(2) \\
1.5 \\
3-4 \\
1-2 \\
4 \\
1 \\
1 \\
1 \\
1 \\
1 \\
1 \\
1 \\
1 \\
2 \\
1\end{array}$ & $\begin{array}{c}0.4(3) \\
0.5(3) \\
3 \\
5-7 \\
2-4 \\
6 \\
2 \\
2 \\
2 \\
2 \\
2 \\
2 \\
2 \\
2 \\
3 \\
2\end{array}$ \\
\hline
\end{tabular}


と見られる部分の体積が $50 \%$ 以上を占める時マクロ䙓 合材（マク口積層膜）と異なる特性が現われると考える

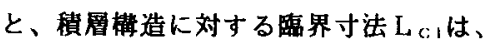

$$
\mathrm{L}_{\mathrm{c} 1} \fallingdotseq 4 \mathrm{~L}_{\mathrm{f}} \text { (積層椣造) }
$$

で与えられる。

また、A，B二相が粒状に分散している系では、表面 層の占める体積が全体の $50 \%$ を越す時マク口复合材料 と界なる特性を有すると考えると、その㾔界寸法上限值 L KK $_{\text {は }}$

$$
\mathrm{L}_{\mathrm{CK}} \fallingdotseq 12 \mathrm{~L}
$$

となる。

さらに、触媒作用のように、表面積か重要な系にあって は、粒子の表面上の一点 Gから半径しっの半球を取って 考えるとき、この半球内に固体の含まれない部分が生ず るような位置Dが必ず存在するので、このような部分の 面積が全表面積の $50 \%$ を越寸とき、この系の特性がマ クロ組䅧の特性と異なると考えると、その郜界寸法の上 限L cs は、分散相が立方体として、次式で与えられる。

$$
\mathrm{L}_{\mathrm{cs}} \fallingdotseq 7 \mathrm{Lr} \text { （立方体分散相）11 }
$$

各種の L c の值を種々の材料について表】に示した。 表中（）内の数值は酸化物中の $\mathrm{L}_{\mathrm{f}}$ が金属中の值とほ ほ同程度と推定して与えた値である。

表 1 に示すように、ナノ複合材料の臨界寸法の上限は 0. $5 \mathrm{~nm} \sim 5 \mathrm{~nm}$ で、結合力が主役をなすような特性 においては、これ以下の組嬂でなければ、ナノ化の効果 は余り期待できないと考えられる。

$3 \cdot 2$ 線形力学特性、特に弾性率から

$\mathrm{A}$ 相中にB相が分散した複合材料において、A，B各 々の相の弹性率 $\mathrm{E}_{\mathrm{A}}, \mathrm{E}_{\mathrm{B}}$ が $\mathrm{E}_{\mathrm{B}} \gg \mathrm{E}_{\mathrm{A}}$ である時は、線形力 学の立場からこの复合材料に下記の形のスケーリング則 が成り立つ4゙。なわち、

$E(\psi, n \ell, W) \equiv E\left(\psi, \ell, n^{3-D} w\right)$

ここにEは複合材料の弾性率、 $\phi$ は複合材料中の分散相

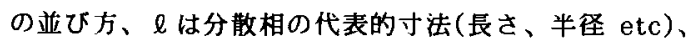
wは分散相全体の量（重量または体積）、Dは分散相の 形状の次元（一次元的であれば $\mathrm{D}=1$ ，平板： $\mathrm{D}=2$ ， 三次元：D=3）である。また、(9)において分散相は寸 法が変わっても形は相似形であると仮定されている。

(9)によれは如何なる形状の分散相においても、如何に 寸法を小さくしても、これに対応する特性（弾性率）の 複合材料をマクロ的寸法の褯合材中の分散相の量を增娍 することによって作りうる。すなおち、ナノ奻果は生じ ない。特に三次元的形状の分散相においては寸法效果は 全く生しないことを(9)は示している。
(9)はしかしながらマトリクスが全く均質な連続体であ ることを仮定している。それゆえ、連䌇体の仮定が成り 立たなくなる寸法がナノ効果の現われる臨界寸法と考え られる。具体的には前節の $L_{\mathrm{Cl}}, L_{\mathrm{Cc}}, \mathrm{L}_{\mathrm{ck}}$ などがこの 場合にも䔔用される。またマトリクスがポリマである場

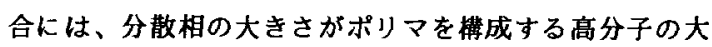
きさより小さくなると、応力の伝達に寸法効果が生じな くなると推定されるので、この棈成要素たる高分子の寸 法L $\mathrm{P}$ が界寸法L $\mathrm{ce}$ となると考えられる。すなわち、

$$
\begin{aligned}
& \mathrm{L}_{\mathrm{CE}} \fallingdotseq \mathrm{L}_{\mathrm{Cl}} 、 \mathrm{~L}_{\mathrm{CK}} 、 \mathrm{~L}_{\mathrm{CC}} \\
& \mathrm{L}_{\mathrm{CE}} \fallingdotseq \mathrm{L}_{\mathrm{P}} \sim 10 \mathrm{~nm} \quad \text { (ポリマ) }
\end{aligned}
$$

また、䙓合体の構成粒子の粒烃が $100 \mathrm{~nm}$ 以下になる と、外力の下で一様に変形するとされているので5)、強 度がマクロ的複合材料のそれより画期的に上昇し始める 臨界寸法L coは、

$$
\mathrm{L}_{\mathrm{CD}} \fallingdotseq 100 \mathrm{~nm}
$$

と考えられる。

\section{$3 \cdot 3$ 磁気的特性から}

強磁性は多数の原子の協力現象であることが古くから 知られており、F e，Coなどでは粒子がコロイド的に なると超常磁性に変わることが知られているら。机粒 径は 20ー50 n mとされている。この点から考えて、 強磁性に関するナノ䙓合材料臨界寸法 L c m は、

$$
\mathrm{L}_{\mathrm{CM}} \fallingdotseq 100 \mathrm{~nm}
$$

\section{としてよいであろう。}

磁気的性質に関する他の重要な特性は抗群力 $\mathrm{H}_{\mathrm{c}}$ であ る。 $\mathrm{H}_{\mathrm{c}}$ は磁の壁動の易さで定まり、磁壁移動に対す る抵抗は磁性体内の析出物、空孔などの欠陥と静磁工ネ ルギとされている。析出物等の寸法、間隔は組樴寸法に 大略比例し、通常組娬が小さくなるほど抵抗が增大し、 $\mathrm{H}_{\mathrm{c}}$ が高くなる。孤立砤粒子でも $\mathrm{H}_{\mathrm{c}}$ と粒径はマクロな唏 性体と類似の関係にある。そして政粒子系では粒径が磁 壁の厚さ程度 $(10 \mathrm{~nm})$ で最大になり、1 $\mathrm{nm}$ では $\mathrm{H}_{\mathrm{c}}$ 气0となることが知られている。マクロな磁性体におい ても、析出物等の寸法が $20 \mathrm{~nm}$ 以下では磁壁の持つエ ネルギが静磁エネルギを上回ると推定されているので?! 組織寸法が磁貹の厚さ $\mathrm{d}$ w以下になれば、磁壁内に存在 する久宿の数は磁壁の位目にほとんど無関係となり、磁 垶移動に対する抵抗は砤隇すると推定される ${ }^{81}$ 。即ち、

$$
\mathrm{L}_{\mathrm{CH}} \leq \mathrm{d} \mathbf{w}
$$

は一つの侮界寸法である。dwは20 nm（M n S b ) -100nm (Fe) とされているので9)、

$$
L_{C H} \fallingdotseq 20 \mathrm{~nm}
$$


がHcに吋する罳界寸法としてよいであろう。

強詮奄性も協力現象であることが知られており、ドメ イン寸法等から考えて、ナノ襩合材料的陽界寸法 L C 強磁性同様、次のように推定される。

$$
\mathrm{L}_{\mathrm{CF}} \fallingdotseq 100 \mathrm{~nm}-1 \mu \mathrm{m}
$$

\section{$3 \cdot 5$ 光学的特性}

光との相互作用で考えると、橧合材料の組織寸法の踀 界值 L coは光の波長程度と考えられる。すなわち、

$$
\mathrm{L}_{\mathrm{co}} \fallingdotseq \lambda / 3 \pi \sim \lambda \fallingdotseq 100 \mathrm{~nm}
$$

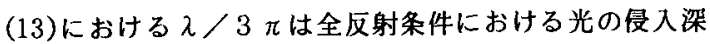

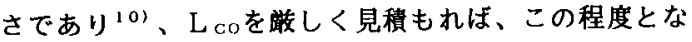
ろう。L coでは反射率も变わり始めると考えられる。

また、THG（三次光学効果）に関しては粒径が

$100 \mathrm{~nm}$ 程度になるとこの効果が生ずるとされておりり この点でも、次のように考えられる。

$$
\mathrm{L}_{c o} \fallingdotseq 50 \mathrm{~nm}(\mathrm{THG})
$$

\section{$3 \cdot 6$ 結晶核の立場から}

$\mathrm{A}$ 相が粒状で $\mathrm{B}$ 相中に分散する複合材料においては、 A相の寸法が結晶核に近づくと、A相は結晶としての安 定性を失ない始めると考えられる。すなおち、結晶核よ り小さな分散相を持つ複合材料はマクロな複合より高い 励起状態にあり、特性が異なると推定される。この立場 では結晶核の寸法がナノ被合材料の䠛界寸法の上限 L CN を与える。

結晶核の寸法 $\gamma^{*}$ は、A 相と B 相の間の界面エネルギ $\gamma_{\mathrm{A}}, \mathrm{B} 、 \mathrm{~A}$ 相がB相中に一様に分散している状態から結 晶として核出する時の単位体積当たりの自由エネルギ変 化 $\Delta \mathrm{F}_{\mathrm{v}}$ から与えられ(2)、これを用いて、

$$
\mathrm{L}_{\mathrm{GN}} \fallingdotseq \gamma^{*}=-2 \gamma_{\mathrm{A}, \mathrm{H}} / \triangle \mathrm{F}_{\mathrm{V}} \fallingdotseq 0.5 \mathrm{n} \mathrm{m}
$$

\section{3・7 界面層中の原子数から}

前章で述べたように、界面周中の原子数もナノ複合材 料の特街的な数である。この数が粒子内部の数の $50 \%$ を上回る䉼径を㽬界寸法 L c とすると、表面層を原子層 一層とし、粒子を球形、あるいは立方体として、 L C 次のように与えられる。

$$
\left.\begin{array}{cl}
\mathrm{L}_{\mathrm{CB}} \fallingdotseq 1.2 \mathrm{~nm}(\text { 球状分散相 }) \\
\mathrm{L}_{\mathrm{CB}_{\mathrm{B}}} \fallingdotseq 0.7 \mathrm{~nm}(\text { 立方体状分散相 })
\end{array}\right\}
$$

（16）は結合力の到達匜離が極めて小さい場合には正しい が、実際は(4)、(5)が罯界寸法としてより正しい評価を与 えると考えられる。

\section{$3 \cdot 8$ 界面エネルギから}

界面エネルギが系のエネルギの $50 \%$ を越すような組

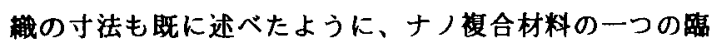
界寸法 L coを与えるか、この傎は本質的に結晶核の寸法 と同一である。すなわち、

$$
\mathrm{L}_{\mathrm{Cc}}=\mathrm{L}_{\mathrm{cN}} \sim 0.5 \mathrm{~nm}
$$

また、采のエネルギとして界面エネルギを除いて考えれ ば上記の值は 2 倍となる。何れにしても、L cGは、

$$
\mathrm{L}_{\mathrm{CG}} \doteqdot 0 . \quad 5 \sim 1 \mathrm{~nm}
$$

と見ることができる。

（17）、（18）は通常 $\gamma_{\mathrm{AB}}$ が $\Delta \mathrm{F}_{\mathrm{AB}}$ に比して郘めて小さい 系、すなわち分散相と母相が化学的には不活性に近い系 を対象として適用される。しかし複合材料にあっては分 散相と母相とは必ずしも不活性ではなく、見脚け上 $\gamma \mathrm{AB}$ は極めて大となり、平衡論的には $\mathrm{A}, \mathrm{B}$ 両相は化合物 $\mathrm{A}$ ・ B八と移行する。実際には分散相、母相が持つポテン シャル障暨のため、化合物への移行は臨界温度以下では 阻止されている。しかし、完全に接触したA，B両相の 特定な結晶面では障壁は低く、分散相と母相とは界面の 一部で少なくとも原子層一層の化合物を生じていると考 えられる。このような場合、この化合物層の両側の未反 応 A，B相には相互に力が作用し、化合しようとする傾 向が生ずる。この力 $\mathrm{f}$ を一般力 $\left(-\Delta \mathrm{F}_{\mathrm{AB}} / \mathrm{x}, \mathrm{x}\right.$ : 化合 物を生ずるために移動する距崔) から求めると、 $\triangle \mathrm{F}_{\mathrm{AB}}$ $=5 \mathrm{kcal} / \mathrm{mole} 、 \mathrm{x}=0.1 \mathrm{~nm} 、 \mathrm{~A}$ 相、B 相の原子間臣 離=0.1 nmとして、f $\mathrm{f} \fallingdotseq 23 \mathrm{GPa}$ となる。通常の材料 の理想強度が $10-20 \mathrm{GPa}$ であることを考えると、応 力的には化合物層一原子層を介して、分散相と母相が接 すれは、この系は高温でない限り安定になると考えられ る。このような考えでは、化合物層を分散相の一部と考 えれは、分散相の下限值 L $\mathrm{cm}$ は、

$$
\mathrm{L}_{\mathrm{cm}} \fallingdotseq 0.5 \mathrm{~nm}
$$

と推定される。化合物層一原子署を介した A, B両相に 值く力は、力の到達匟離の立場から判断して、理想強度 の $1 / 2$ 以下に低下しており、この立場からも(19)が妥 当な值と考えられる。

$3 \cdot 9$ 量子力学的效果から

単純化された系で考えると、系のエネルギ潐位 $\varepsilon$ は系 の寸法の自乘に逆比例し次の形で与えられる ${ }^{13)}$

$\varepsilon=\left(\hbar^{2} / 2 \mathrm{~m}_{0}\right)(2 \pi / \mathrm{L})^{2}\left(\mathrm{n}_{1}{ }^{3}+\mathrm{n}_{2}{ }^{2}+\mathrm{n}_{3^{2}}{ }^{2}\right)$

ここに $\mathrm{m}_{0}$ わ、 L、 $\mathrm{n}_{\mathrm{i}}$ はそれぞれ電子の筫量、プラン クの常数、系の寸法、整数 $(1 、 2 、 \cdots)$ である。量 子力学的效果におけるナノ寸法効果は、種々の立場から 論じられるが、その一つは系のエネルギ隼位間の差が系 
の格子の熱振動エネルギより大きくなる時に生ずるとす る立場であろう。このような系では、熱振動との相互作 用を介しての直接な䀊移は生じ難くなり、マク口掼合材 料とは異なった特性が生ずると考えられるからである。

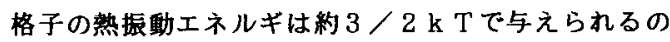
で、エネルギ準位の差がこれを越すのは、系の寸法 Lが 次式の躡界値L cQより小さくなった時である。

$$
\mathrm{L}_{\mathrm{CQ}} \fallingdotseq 3 \mathrm{~nm} \text { (室温近傍) }
$$

上の近似は単純なモテルによっているが、バンドエネ ルギのやや詳しい計算結果でも、励起エネルギがマクロ な系のバンドギャップエネルギから大きく変化し始める

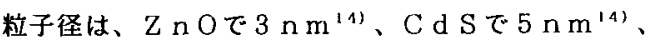
I n S bで $10 \mathrm{n} \mathrm{m}^{14)}$ 、 $\mathrm{PbS}$ b゙ $4 \mathrm{n} \mathrm{m}^{15)}$ とされてい る。また、殿粓子に閉じ込められた励起子の有効ボーア 半径 ${ }^{(5)}$ は C u C l で約 $0.7 \mathrm{~nm} 、 \mathrm{GaAs}$ で 1.4 $\mathrm{nm}$ 程度とされ、粒子径がこれの2 倍以下であれば量子 効果が著しいので、量子光学的な踇界寸法 L COP は、

$$
\mathrm{L}_{\mathrm{COP}} \doteq 5 \mathrm{n} \mathrm{m}
$$

以上をまとめると、ナノ寸法効果が生ずると期待され る臨界寸法の上限および系の安定を与える下限は表 2 に 示寸如く、大略 $50 \mathrm{~nm}-0.5 \mathrm{~nm}$ と推定される。す なわち、ナノ复合材料の生成領域は寸法的に極めて小さ な範曲に制限されると言える。

\section{$\S 4$ ナノ化によって期待される効果}

前章で述べた条件が满足されたと仮定した時、予想さ れる奻果として以下のものが挙げられる。またすでに実 現しているものもある。

Table 2 Critical Size for Various Structure, Property and Controlling Factor in Nano-Composites.

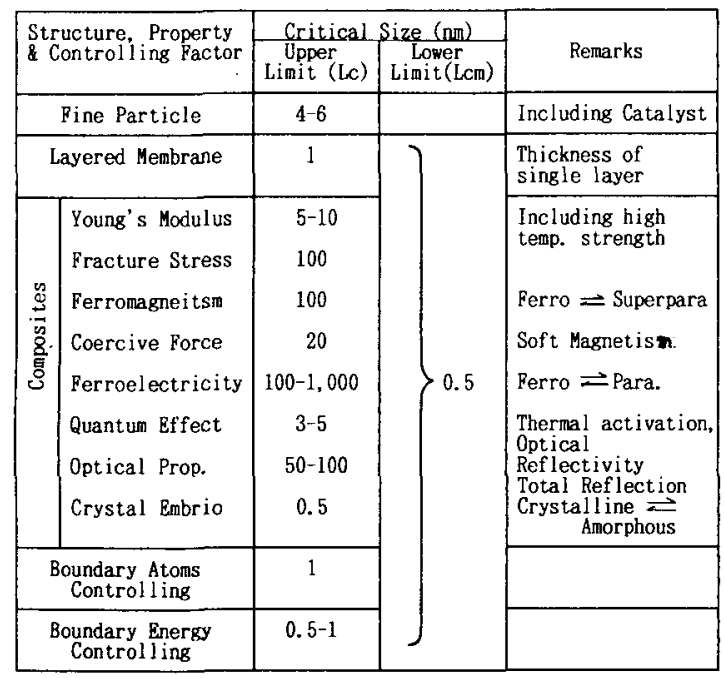

\section{4- 1 化学的特性}

組箋寸法が1〜10 n m以下になると、表面および の下層の粒子の結合力が表面で混合するようになり、化 学的特性で見九ば視合材料を形成する諸粒子の平均的化 学特性がその表面で実現されると考えられる。また系の 構成要素によっては表面を形成する相の化学的特性が著 しく変更を受けると予想される。

化学的特性として最も重要な例は触媒作用であろう。 䖵媒作用が触媒の担体の影䇾を受けることは古くから知 られているが、この影響は多くの因子の総合的作用の結 果であって、必ずしも下地の結合力が表面に担持されて いる触媒の化学的作用と重貴して作用しているためとは 言い切九ない。しかし、最近、化学的作用の重鼻を示唆 する例が現われている。即ち、従来 $\mathrm{A} \mathrm{u}$ は不活性と考え られて来たが、最近、 $\mathrm{Fe} \mathrm{e}_{2} \mathrm{O}_{3}$ etc上に5-100 n m の微粒子としてA uが唀着されるようになり、これが $\mathrm{CO}, \mathrm{H}_{2}$ に対し、低温 $\left(-70^{\circ} \mathrm{C}\right)$ で著しい触媒作用 を呈することが知られるようになってきた ${ }^{17-19) 。 こ の ~}$ 触媒作用は $30 \mathrm{~nm}$ 以下で顕著である、下地酸化物によ って、 $\mathrm{CO}, \mathrm{H}_{2}$ に対する触媒活性が著しく異なる等の 特徽を有し、ナノ的寸法効果が多くの点で生じていると 推定される。また、1-10n mのP d, N i 敉粒子上 でのCOの分解、C 堆積が粒径に著しく依存しているこ

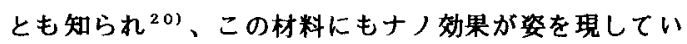
ると考えられる。もちろん、微粒子の触媒作用等が全て 嘖的に粒径依存している訳ではなく、粒径を小さくして も質的変化がないと想定される結果も極めて多い。

\section{$4 \cdot 2$ 光学的特性}

光学的特性でナノ寸法效果の最も著しい例は三次の光 学非線形性（THG）に見られる。C d S x S e 1-xを ドープしたガラスでは、適当な熱処理により粒子径 1$30 \mathrm{~nm}$ m C d S x S e 1-xがガラス中に分散し、この ガラスは励起子準位で三次の非線形感受率がバルク材の $4-5$ 桁大きい $\left(10^{-2} \sim 10^{-3} \mathrm{e} \mathrm{s} \mathrm{u}\right)$ ことが知られ ている ${ }^{11}$ 21,22)。上の值 $1-30 \mathrm{~nm}$ はC d S S e ボーア半径 $(3-5 \mathrm{~nm})$ と同程度の值で、前草で述べ た踀界值に対応している。

光学的には二次の非線形性 ( S H G) に対しても、ナ ノ寸法効果が有効に現われることが期待される。すなわ ち、S HGに関しては、関係する系の非対称性が重要な 役割を担っているが、ナノ椱合材料の粒界では非対称ポ テンシャル場が作られており、ここに吸着及至閉じ込め られた材料は自動的に非対称性を持つと考えられる。非 対称性を与える場としてのナノ襩合材が注目される。

\section{$4 \cdot 3$ 電磁気的特性}

ナノ化によって磁気的には通常强磁性体及び至㜞磁性 
体が得られると予想されるし、実際にもその例は多い。 強磁性におけるナノ効果の影著な例は糟層薄膜（人工格 子合金）における垂直磁化であろう。薄膜における垂直 化の発生は古くから予想されていたが、単原子首程度

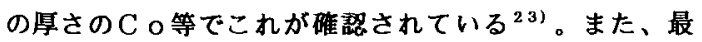
近、 $\mathrm{Fe} / \mathrm{Mg}$ 交互稳層合金で $\mathrm{F}$ e 眉が $0.4 \mathrm{n} \mathrm{m}$ 以下 の㫗さになると垂直碳化の生ずることが見出され、さら にM n / S bでもM n が単層であれば垂直磁化が認めら れている ${ }^{24-26)}$ 。また、Co/Pt， Co/ $\mathrm{Au}$ 等でも C ○が1. $5 \mathrm{~nm}$ m下になると苴磁化が生ずる ${ }^{27) 。 ~}$ このような特殊な磁性材料は光磁気記録材料として注目 されている。なお、上記 $M n / S$ bでは界面は $M n S$ b 構造に近く、また C o / A u, C o / P t で下地膜厚が 垂直磁気異方性に関係し、雨相の強い相互作用の存在を 示している28)。

また、大きな磁気抵抗好果も人工格子合金で認められ ている。当初 $\mathrm{Fe} / \mathrm{C}$ 積層膜で諗められ 20.30$)$ 、最近 は $\mathrm{Ni} \mathrm{Fe} / \mathrm{Cu} / \mathrm{Co} / \mathrm{Cu}$ 積層膜（各膜草 $2.5-$ 5. $5 \mathrm{~nm}$ )でも認められ ${ }^{31 ! 、 し か も ~} 30 \mathrm{G}$ 程度の低 い外部磁場で大きな䃄気抵抗效果が得られている。

また、金属磁性体粒子を $50 \mathrm{~nm}$ 程度の膜状 $\mathrm{A} 1_{2} \mathrm{O}_{3}$ で分離することにより、高い飽和磁東密度（～ $10 \mathrm{k} \mathrm{G})$ と高い電気抵抗 $\left(10^{11} \Omega \mathrm{c} \mathrm{m}\right)$ を有する材

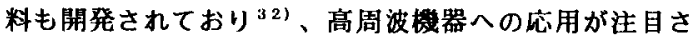

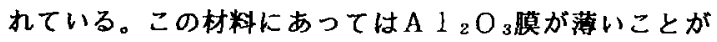
重要で、この点でのナノ化が重要な鍵となる。

また、最近、鉄基の超做細結晶㜞磁性体が開発されて

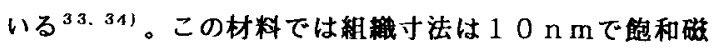
束密度 $(1-1.5 \mathrm{~T})$ 、比透磁 $\left(10^{4}-10^{5}\right)$ 共 に高くかつ $\mathrm{H} \mathrm{c}$ が極めて小さい( 0.35 $\mathrm{A} / \mathrm{m})$ 。

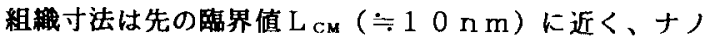
襩合材としての特性が現れているのではないかと考えら れる。

上記のように電磁気的特性に関しては、ナノ化により バルク材では得られない特性がすでに得られており、こ の面での開発が今後一層㹡がるものと考えられる。電磁 気的特性でナノ䙡合材料に著しい進屡が見られるのは、 臨界寸法が比較的大きい点に一因があると考えられる。

\section{$4 \cdot 4$ 機械的- 熟的特性}

租戗寸法が $\mathrm{L} \mathrm{c}$ 程度になると、楼する相同志の相互 作用のため両相の中間的な相が出現し、条件によっては 弾性率の上昇が見込ま机、高弾性率材料の創製が期待さ れる。マクロ的材料では、 $\alpha \cdot \mathrm{T}_{\mathrm{m}} \fallingdotseq$ 一定（ $\alpha$ : 热膨張 率、 $\mathrm{T}_{\mathrm{m}}$ : 萢点) また、 $\alpha \cdot \mathrm{E}=\mathrm{C}+\mathrm{AT}_{\mathrm{m}}+\mathrm{B} \mathrm{T}_{\mathrm{m}}{ }^{2}(\mathrm{E}$ : 弹性事、 $A, B, C$ : 常数 ${ }^{35)} 、 \sigma_{\mathrm{id}} \propto \mathrm{T}_{\mathrm{m}}\left(\sigma_{\mathrm{id}}\right.$ : 理想强度） ${ }^{3)}$ が成り立つので、高強度材料=高融点、高 弾性事、低整騀張材料となり、他材料との接合、復合化
に問題を生ずる。 $\alpha$ の低いこと、Eの大きなことことは 原子の周りのポテンシャルの対称性と関連している。ナ ノ複合材料においては相境界に非対称性ポテンシャルが 発生するので、上記の関保は大巾に変更を受け、高弾性 率で高膨張の材料等の出現が期待される。

強度について文えは、先に述べたように、100 $\mathrm{nm}$ 以下になれは高强度の材料が期待される。特にナノ複合 材料における高強度化は母相における过りの抑制によっ て生ずるので耐热盜度も同時に上昇する ${ }^{3)}$ 。すなわち、 耐熱・高強度材料の実現が期待される。

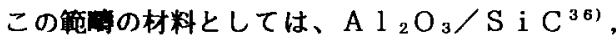
$\mathrm{MgO} / \mathrm{S} \mathrm{i} \mathrm{C}^{37)}, \mathrm{S} \mathrm{i}_{3} \mathrm{~N}_{4} / \mathrm{S} \mathrm{i} \mathrm{C}^{38)}$ の組合せが举 げられよう。分散相 $\mathrm{S}$ i Cの寸法は $100 \mathrm{~nm}$ 程度また はそれ以下で、これにより $\mathrm{A} 1_{2} \mathrm{O}_{3} 、 \mathrm{MgO}$ Oで 1400 ○まで强度を轻持する材料が得られ、また $\mathrm{S} \mathrm{i}_{3} \mathrm{~N}_{4}$ の高 強度化も実現されている。有機／無機の組合せでは天然 物に例が見られ、雲丹の殸のカルサイト（微結晶）／蛋 白の系では、単純なカルサイトに見られる $\left\{\begin{array}{lll}1 & 0 & 4\end{array}\right\}$ 破 面は生ぜず、 $\left\{\begin{array}{l}3 \\ 3\end{array} 1\right\}$ 破面が生ずることが知られてお り、ナノ葆合材における無機/有機の相互作用が暗示さ れている39)。また、ナイロンー6/モンモリロナイト

（粘土笻物； $200 \times 200 \times 1 \mathrm{~nm}^{3}$ ）の系 ${ }^{40)}$ ではナイロンー 6 の高温弹性摔に著しい向上が認められ、無機/有機ナ ノ复合材料に機城的特性で大きな期待が持たれる。

\section{$4 \cdot 5$ その他}

前節までに具体的特性について述べたが、ナノ複合材 料のもう一つの期待は外部刺激による特性変化にある。 すなわち、母相に外部刺 $\mathrm{x}$ (伈力、電場 etc)に対して 非線形的に変化する特性 $\psi$ がある場合、 $\mathrm{x}$ と同種の刺 $\Delta \mathrm{u}$ を分散相を介して与えることが可能であれば特性 は、 $\psi(\mathrm{x}) \rightarrow \psi(\Delta \mathrm{u}+\mathrm{x}) 、 \psi$ の変化 $\phi^{\prime}$ は $\phi^{\prime}(\mathrm{x}) \rightarrow$ $\phi^{\prime}(\Delta \mathrm{u}+\mathrm{x})$ となる。 $\phi^{\prime}(\mathrm{x}) \neq \phi^{\prime}(\Delta \mathrm{u}+\mathrm{x})$ である ので、 $\psi$ の応答(物性)は $\Delta \mathrm{u}$ によって変化することにな る。この裉合材がナノ複合材であることが望ましいのは ナノ複合材であれは变化が全相にわたって均一である事 ナノ分散によって $\Delta$ uを小さくしうることなどである。 この例の一つを、因 2411 に示した。母相はシリコン 系ゴムであり、分散相は診電性液晶である。ゴムに電圧 を用加すると、分散相に電界が引き込まれ、分散相間に

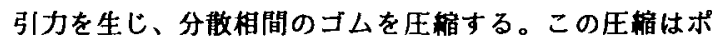
アソン比を介して張力埸を龟场と垂直な方向に誝起し、 この方向に歪みを生ずる。この歪みはゴムの非楾形的応 カ一歪曲線の原点を变え、結果としてゴムの弹性率 $\mathrm{G}_{1}$ は電界Eによって制御される。電界による分散相の分布 変化も $G_{1}$ を変えている可能性もある。同種の材料は他 にも考えられ、非楾形ナノ複合材料に期待が持たれる。 


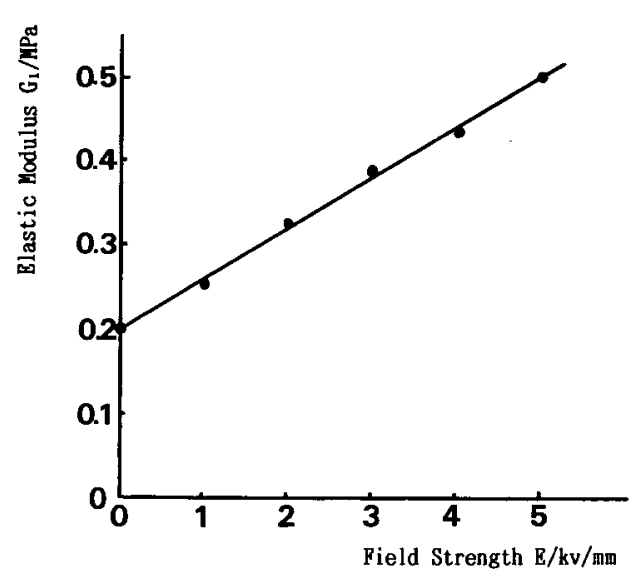

Fig. 2 Shear Modulus, $G_{1}$, as a function of electric field strength, E, for the rubber having special dispersoids.

\section{$\S 5$ 結 当}

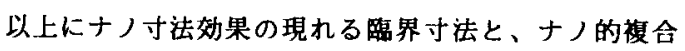
材料が得られたとした時に期待される特性、すでに得ら れている最近の結果などについて述べた。ナノ褯合材料 はバラエテイに富み、捊来の材料と思われるし、臨界寸 法も、それぞれ異なる立场から独自の值が定まる性質の ものである。これらの点について、一層多くの分野の開 拓されることが望まれる。

本稿を草するに当り、大阪大学名誉教授、近㙨大学教 投藤田㕕志先生には多大の教示を頂きました。特に磁壁 移動の抵抗については深く教示頂きました。䈍くお礼申 し上げます。また、豊田中央研究所元広友美氏には光学 的特性に関し、兵頭志明氏には化学的特性につき、中村 保氏には触媒特性につき多くの教示を頂きました。管く お礼申し上げます。

\section{文輀}

1）上垣外䇙已：粉体および粉末治金37(1990)1096

2) 0. Kamigai to: J. Mat. Sci. Lett. $\underline{7}(1988) 529$

3 ）上垣外修己：粉体および粉末冶金 $37(1990) 837$

4 ) 小岩井明㢁、兵頭志明、元広友美、野田正治、上垣 外修己: 粉体粉末治金協会講演概要集 (H 2) p. 49

5) H, Fujita ; "Advanced Mat. I"(Proc. Special Symp. on Advanced Mat. Tokyo(1988) P. 35

6) W.C.Elmore; Phys. Re0. $\underline{54}(1938) 1092$

7 ) 近角聘信: ”物質の磁性”（有山、三宅、茅、武藤、 小谷、永宫著、共立出版 S35）P. 310

8) 藤田広志 : 私信

9）永宮健夫：" 物貿の磁性”（有山、三宅、茅、武藤、 小谷、承宫著、共立出版 S35) P. 26

10) M. Born and E. Wolf : "Principles of Optics"
(Pergamon Press. London, 1959)P. 47

11) N.F. Borrelli, D. W. Hall, H. J. Holland and D.W. Smith: J. Appl. Phys. 61(1987)5399

12) W. D. Kingery:"Introduction to Ceramics"(John Wiley \& Sons, N. Y. 1967)P. 294

13）松原武生：”物性 I（井上、大沢、片山、久保、高 木、寺本、戸田、豊田、中鳮、早川、林、松原、丸 森編、岩波書店、1973）P.110

14) L. Brus; IEEE J. Quantum Elect. QE22(1986)1909

15) Y. Wang, A. Suna \& W. Mahler;M. R. S. Symp. Proc. 109(1988)187

16）花村栄一;応用物理 $59(1990) 325$

17）春田正媇；表面28 $(1990) 333$

18) M. Haruta, T. Kobayashi, H. Sano \& N. Yamada;Chem. Lett 1987(1987) 405

19）春田正毅；化学と工業出(1987)306

20) D. L. Doeling. H. Poppa, J. T. Dichinson; J. Vac. Sci. and Technol. 18 (1981) 460

21) R.T.Jain and K.C. Lind;J. Opt. Soc. Am. $\underline{73}(1983) 647$

22）湯本潤司、浅原慶之；固体物理24(1989)925

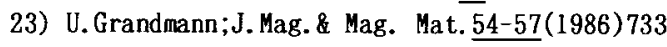

24) T. Shinjo, N.Hosoito, K. Kawaguchi, N. Nakayama,

T. Takada \& Y. Endoh; J. Mag. \& Mag. Mat. 54-57(' 86) 737

25) F.A. Fol kening, B. T. Jonker, J. J. Krebs, N.C. Koon and G.A.Prinz;J. Appl. Phys. $\underline{63}(1988) 3869$

26) T. Sh injo, N. Nakayama, I.Mor $\bar{i} \tan i$ and Y.Endoh; J. Phys. Soc. Japan. $\underline{55}(1986) 2512$

27) F. J.A. M. Greidanus, W. B. Zeeper, F. J. A. den Broader W. F. Godl ieb \& P. F. Carcia;Appl. Phys. Lett. 54(1989)2481

28）平塚信之、田口和宏、市川智徳、杉本光男; 粉体粉 末治金協会講演概要集 (1990，春) P. 222

29) M. N. Baibich, J.M. Broto, A. Fert, F. Neuyen Van

Dau, F. Petroff, P. Etienne, G.Greuzet, A. Friederich

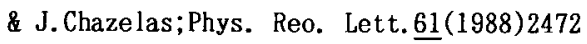

30) G. Binasch, P. Gruenberg, F. Saurenbach and W. Zinn; Phys. Rev. B39(1989) 4828

31)T. Shin jo, H. Yamamoto;J. Phys. Soc. Japan59(90)3061

32）釷宮公一、㕕田健、里見三男、井上修; 粉体おょび 粉末冶金37(1990) 333

33) Y. Yoshizawa, S. Oguma, K. Yamauchi; J. Appl. Phys 64(1986)6044

34）吉沢克仁、山内清隆; 日本金属学会誌53(1989)241

35) O. Kamigai to;J. Mat. Sci. Lett. 10[4](1991) (in peinring)

36) K.Ni ihara and A. Nakahira;Proc. MRS Intern. Meeting on Advanced Mat. Vol.5(1989)P. 129

37) K. Ni ihara;Proc.1st Intren. SAMPE Symp(' 89)P1120

38) K. Niihara and A. Nakahira;Proc. MRS Intern. Meeting on Advanced Mat. Vol.5(1989)P. 421

39) A. Berman; Nature $\underline{331}$ (1988) 546

40) Y. Fukushima;Clay Min. 23

41）志賀亨、太田隆、佐藤紀夫、広瀨美治、岡田茜、倉 内紀雄；高分子学会予稿集39(1990)P. 1170 